\title{
Isotherm and pH Effect Studies of Tetracycline Drug Removal from Aqueous Solution Using Cobalt Oxide Surface
}

\author{
Hawraa Kassem Hami ${ }^{*}$, Ruba Fahmi Abbas ${ }^{* *}$, Ali Amer Waheb ${ }^{* * *}$, Dhifaf A. Abdul abass, Marwa \\ A. Abed and Asmaa A. Maryoosh \\ Department of Chemistry, Collage of Science, Al-Mustansiryiah University, Baghdad-Iraq. \\ *Corresponding Author: hawraak2012@uomustansiriyah.edu.iq. \\ ** Corresponding Author: rubaf1983@uomustansiriyah.edu.iq. \\ **** Corresponding Author: alichance80@uomustansiriyah.edu.iq.
}

\begin{abstract}
Tetracycline adsorption on the surface of cobalt oxide studied in this work to determine the appropriate conditions for increasing the efficiency of adsorption by changing the temperature, adsorbed dosages, concentration, contact time and $\mathrm{pH}$. The results showed that the rate of adsorption decreased by increasing the temperature and concentration and at 45 minutes with $0.1 \mathrm{gm}$ of $\mathrm{Co}_{3} \mathrm{O}_{4}$. The influence of $\mathrm{pH}$ on adsorption at $\mathrm{pH}(1.2,6,8)$ was studied and concentration with a linear range of $(20-70 \mathrm{mg} / \mathrm{l})$, the adsorption ratio decreased by increasing the concentration at the same $\mathrm{pH}$. The point of zero charges $\mathrm{pHzc}$ calculated and found to be equal to 7.2. Both Langmuir and Freundlich isotherm studied. The result showed a good agreement with Freundlich linear model. [DOI: 10.22401/ANJS.22.2.02]
\end{abstract}

Keywords: Isotherm, Doxycycline, Adsorption, Cobalt Oxide, The point of zero charges pHzc.

\section{Introduction}

Antibiotics are classified as contaminants of the environment where they were found in soils, surface water and groundwater even in drinking water [1]. They are transferred to the environment through human and animal waste [2]. That the widespread use antibiotics it can cause a diversity of harmful influences like chronic toxicity, reduce human immunity, and diffuse in antibiotic-resistant genes [3]. Antibiotic contamination is a potential menace to human soundness. It is, therefore, necessary to look for ways to remove these pollutants. Antibiotic medication tetracycline (TC), is one sort of the most generally utilized antiinfection agents, display a range of active antibiotics in the environment. Tetracycline has been reported to cause bacterial resistance leading to the destruction of the environment and the threat of human soundness through bioaccumulation in the food chain. Therefore, tetracycline is removed from the water environment is necessary [4]. A number of operating conditions have been sophisticated to eliminate tetracycline from an aqueous solution in the last years, those encompass ion exchange, photo electro catalytic degradation, coagulation, membrane processing, ozonation and adsorption. Adsorption processes are one of the most widely used processes for the removal of antibiotics. It is characterized by its high efficiency, ease of use, low cost and no risk of toxic by-products [5]. Tetracycline was chosen because of its wide application in clinical medicine, aquaculture and stockbreeding, as well as its environmental importance. The effect of $\mathrm{pH}$ on tetracycline adsorption was studied in detail. The adsorption isotherm was studied to understand the behavior of tetracyclineon cobalt oxide surface [6].

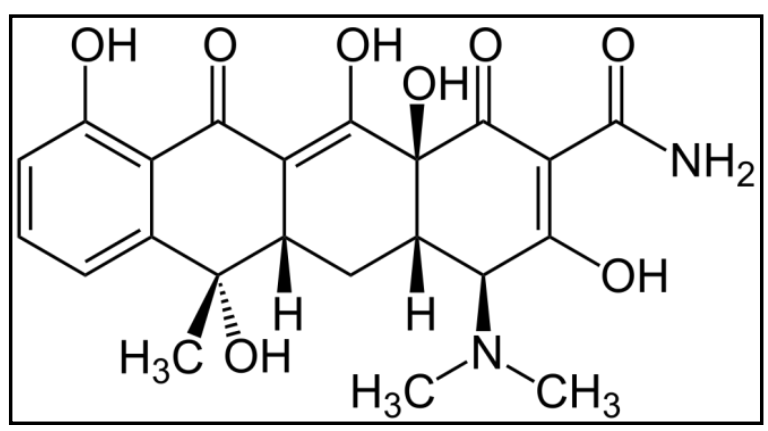

Fig.(1): Structure of tetracycline. 


\section{Experimental}

Apparatus

$\mathrm{pH}$ meter (Hana), UV-Visible Spectrophotometer (CARY 100, VARIAN Co.) with $1 \mathrm{~cm}$ quartz cell and shaking water path (BS-11degetal, JEIO Korea, TECH).

\section{Reagent}

The chemicals reagents in this research are:

1.Tetracycline powder $\left(\mathrm{C}_{20} \mathrm{H}_{24} \mathrm{~N}_{2} \mathrm{O}_{8}\right.$, $444.4 \mathrm{~g} / \mathrm{mol}$ ) received from SDI-Iraq Company without further purification. A stock solution of tetracycline $(1000 \mathrm{mg} / \mathrm{L})$ was prepared by dissolved $0.1 \mathrm{gm}$ of tetracycline in $100 \mathrm{~mL}$ distilled water. Every working standard solution was freshly prepared by diluting the stock solution with distilled water.

2.Cobalt Oxide (BDH) as absorbent.

3.Sodium hydroxide (ka-Granite Switzerland) (0.1N) and Hydrochloric acid (BDH, England) $(0.1 \mathrm{~N})$ to control $\mathrm{pH}$.

\section{Adsorption Experiments}

The Batch experiments were performed using the batch equilibration techniques in a temperature-controlled water bath shaker. For the adsorption equilibrium experiments, a fixed adsorbent dose $(0.1 \mathrm{gm})$ was weighed into $100 \mathrm{~mL}$ conical flasks containing $10 \mathrm{~mL}$ of different initial concentrations of tetracycline. The mixture was shaken for $0.45 \mathrm{~min}$ at $37.5^{\circ} \mathrm{C}$ until the equilibrium was obtained. $\mathrm{pH}$ values of tetracycline solutions were adjusted by $0.1 \mathrm{~N} \mathrm{HCl}$ and $\mathrm{NaOH}$.

\section{Analytical Methods}

An amount of known concentration of tetracycline was transferred in a flask and mixed with $0.1 \mathrm{gm}$ of Cobalt Oxide and using a thermostatic shaker bath for $45 \mathrm{~min}$. at the maximum wavelength $(\Lambda \max =414 \mathrm{~nm})$. At equilibrium, the amount of adsorbed $\mathrm{q}_{\mathrm{e}}(\mathrm{mg} / \mathrm{g})$, calculated from:

$$
\mathrm{qe}=\frac{(\mathrm{Co}-\mathrm{Ce}) \mathrm{V}}{\mathrm{m}}
$$

Where, $\mathrm{C}_{0} \quad(\mathrm{mg} / \mathrm{L})$ is the initial concentration of tetracycline $(\mathrm{mg} / \mathrm{L}), \mathrm{C}_{\mathrm{e}}$ equilibrium concentration, $\mathrm{V}(\mathrm{L})$ is the solution volume and $\mathrm{m}$ is the weight of $\mathrm{Co}_{3} \mathrm{O}_{4}$ powder.
Removal percentage (g) for tetracycline can be calculated as follows [7, 8]:

$$
\text { Removal\% }=\frac{(\mathrm{Co}-\mathrm{Ct})}{\mathrm{Co}} \times 100
$$

\section{Result and Discussion \\ Calibration curve}

A stock solution of tetracycline solution $(1000 \mathrm{mg} / \mathrm{L})$ was prepared to fix a certain weight of the tetracycline in water. A series of solutions were prepared within the range (20-70 mg / L) and their absorption was measured at $\left(\lambda_{\max }=414 \mathrm{~nm}\right)$. The absorption coefficient was calculated by drawing the absorption values against the concentration and was $\mathrm{a}=0.0273 \mathrm{gm}^{-1}$. L. $\mathrm{cm}^{-1}$.as showing in Fig.(2) [9].

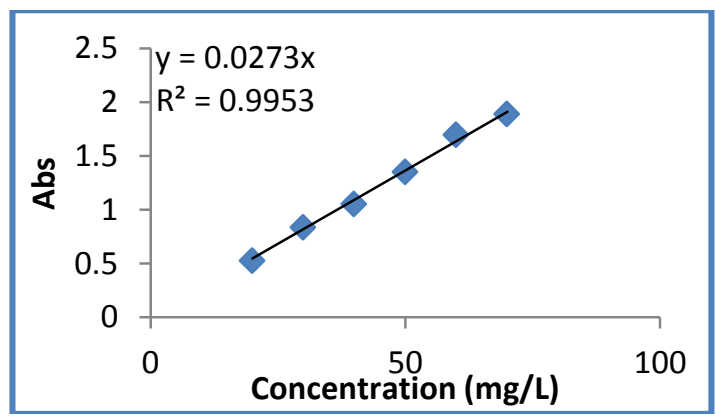

Fig.(2): Calibration curve of the tetracycline.

\section{1- The influence of the initial concentration}

Adsorption reaction of tetracycline drug was performed using different concentrations of $(20-70 \mathrm{mg} / \mathrm{L})$ at $\mathrm{pH} \quad 6$ and reaction temperature of $37.5^{\circ} \mathrm{C}$ for 45 minutes. The ratio of tetracycline removal decreased with the increase in the initial concentration of tetracycline Fig.(3) It can be explained that all the active-sites on the surface of the substance adsorbed become saturated with a certain concentration and an increase in concentration does not affect the rate of adsorption[10,11].

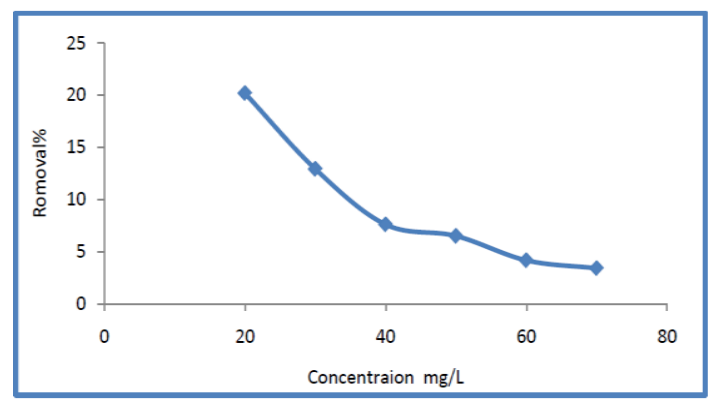

Fig.(3): Effect of initial concentration on tetracycline adsorption. 


\section{2- The influence of adsorbent dosages}

The influence of surface mass was studied on tetracycline adsorption where the experiment was performed by adding (0.05, $0.1,0.2,0.3$ and $0.4 \mathrm{gm}$ ) to $50 \mathrm{mg} / \mathrm{L}$ at $\mathrm{pH} 6$ and $37.5^{\circ} \mathrm{C}$ for 45 minutes. The rate of removal rose rapidly with increased of the weight of $\mathrm{Co}_{3} \mathrm{O}_{4}$ doses. The best rat of adsorption removed was recorded with $0.1 \mathrm{gm}$ of $\mathrm{Co}_{3} \mathrm{O}_{4}$, and any increase in surface amount more than $0.1 \mathrm{gm}$ did not affect in the adsorption rate. This is due to lower concentration of tetracycline and the height available effective sites on the adsorbed surface. As showing in Fig.(4)[ 12,13]

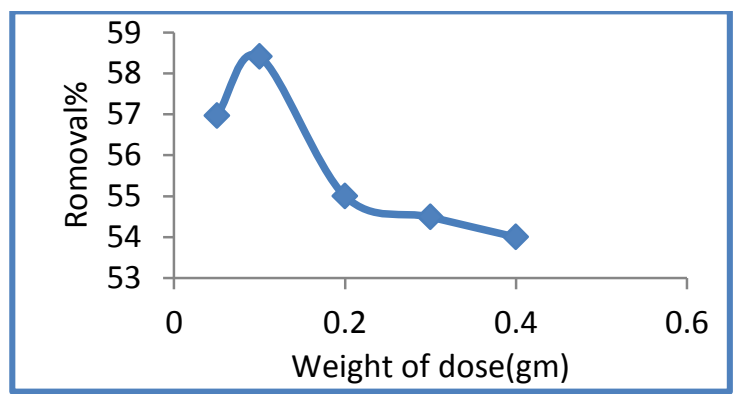

Fig.(4): Effect of the adsorbed amount on tetracycline adsorption.

\section{3- The influence of temperature}

Adsorption was studied at various temperatures $\left(37,47\right.$ and $\left.57^{\circ} \mathrm{C}\right)$, concentration $50 \mathrm{mg} / \mathrm{L}, \mathrm{pH} 6$ for 45 minutes observed from Fig.(5) decreased percentage tetracycline adsorption with temperature increase from $37^{\circ} \mathrm{C}$ to $57^{\circ} \mathrm{C}$. These results indicate that this process is exothermic and the adsorption is physical, so the high temperature will have a negative impact on adsorption [14.15].

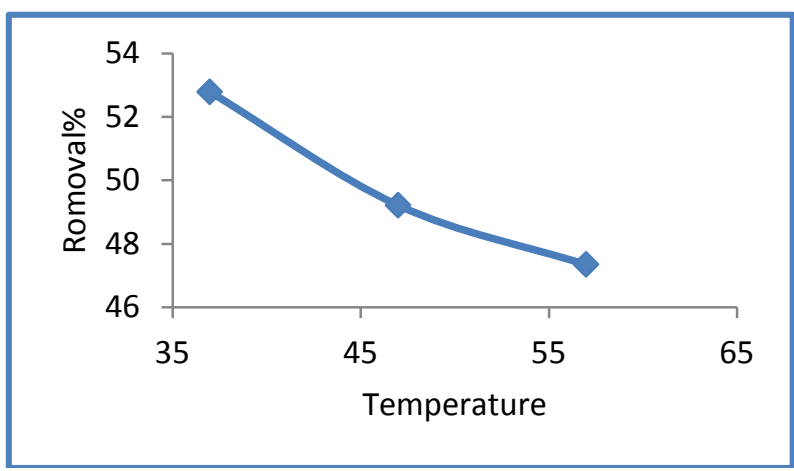

Fig.(5): Effect of temperature on tetracycline adsorption.

\section{4-Influence of contact time}

The removable of tetracycline onto cobalt oxide was performed at a different times (15$90 \mathrm{~min}$ ) and increased gradually every 15 minutes. Initially, the removal rate increased with time increasing to 45 minutes from the contact time, and after that the adsorption rate became practically constant. This happened because as time progresses effective sites on the adsorbed surface are covered with tetracycline and further no adsorption occur [16,17]. Fig.(6) summarize the percentage removal behavior at various contact time.

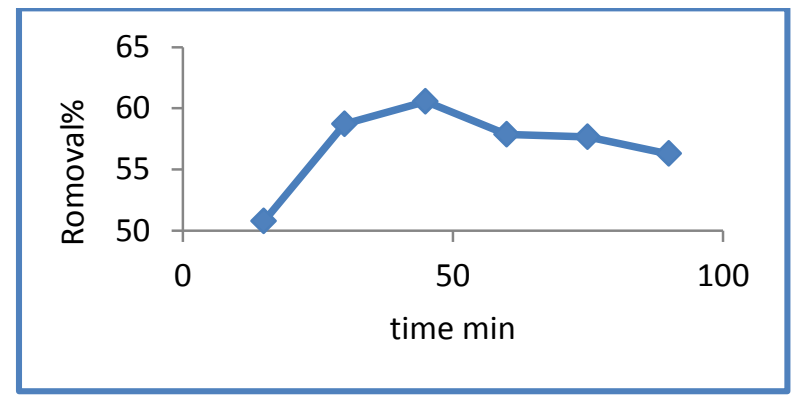

Fig.(6): Effect of time on tetracycline adsorption.

\section{5-Influences of solution $\mathrm{pH}$}

The removal of the medicines in their aqueous solution depends heavily on the $\mathrm{pH}$ of the solution that effect in the adsorbent surface charge, the ionization degree. Influence of initial $\mathrm{pH}$ on the adsorption capacity of tetracycline on cobalt oxide was studied at $\mathrm{pH}$ $(1.2,6$, and 8$)$ at the adsorbent dosage of $0.1 \mathrm{gm}$, using concentration $(20-70 \mathrm{mg} / \mathrm{l})$ at $37 \mathrm{C}^{\mathrm{o}}$.

Tetracycline has changing charges on different sites depending on $\mathrm{pH}$ solution, when $\mathrm{pH}$ is less than 4, Tetracycline be cation $\left(\mathrm{TCH}^{1+}\right)$, because of to the protonation of dimethyl ammonium group. At $\mathrm{pH}$ (3.5 -7.5), Tetracycline be a zwitterion $\left(\mathrm{TCH}_{2}{ }^{0}\right)$, because of to the loss of a proton from the phenolic diketone moiety. At $\mathrm{pH}$ higher than 7 , Tetracycline be anion $\left(\mathrm{TCH}^{-}\right.$or $\mathrm{TC}^{2-}$ ) due to the loss of protons from the tri-carbonyl system and phenolic di-ketone moiety. The result show that the adsorption then decreases as the $\mathrm{pH}$ is increased that indicate the dominant of cation exchange mechanism of tetracycline's adsorption onto cobalt oxide [18-21]. 




Fig.(7): Increasing of pH caused different forms of the tetracycline.

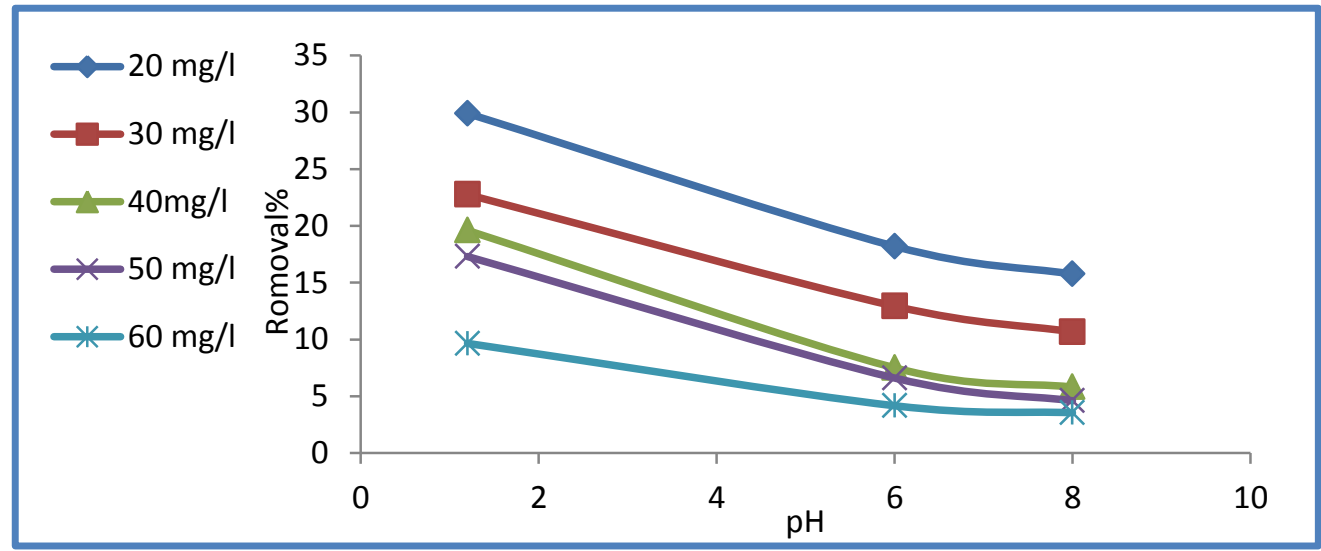

Fig.(8): Effect of $\mathrm{pH}$ on tetracycline adsorption at different concentrations.

\section{Point of zero charges (pHzc)}

The point of zero charge is the $\mathrm{pH}$ at which the adsorbent surface is neutral. The amounts of positive and negative electric charges are equal. Below this value, the surface is positively charged; beyond this value, it is negatively charged [22]. $\mathrm{pHzc}$ was determined by the salt addition method. $0.01 \mathrm{gm}$ of $\mathrm{Co}_{3} \mathrm{O}_{4}$ added to $10 \mathrm{ml}$ volumetric flask containing $(50 \mathrm{mg} / \mathrm{l})$ of tetracycline were add into 5 flasks in different initial $\mathrm{pH}(\mathrm{pHi})$ solutions $(1.2,2.5$, 6,8 and 10). $\mathrm{pH}$ values were altered using $(0.1 \mathrm{~N})$ of $\mathrm{NaOH}$ and $\mathrm{HCl}$, then $0.01 \mathrm{gm}$ of $\mathrm{Co}_{3} \mathrm{O}_{4}$ was added into all flasks. The $\mathrm{pH}$ of solutions was measured after 48 hours, this $\mathrm{pH}$ called the final $\mathrm{pH}(\mathrm{pf}) . \Delta \mathrm{pH}=(\mathrm{pHi}-\mathrm{pHf})$ values are plotted against the pHi values PZC value was identified at the $\mathrm{pH}$ when $\Delta \mathrm{pH}$ was zero. [23]. pHzc of $\mathrm{Co}_{3} \mathrm{O}_{4}$ was determined at pH 7.2 as shown in Fig.(9). So $\mathrm{Co}_{3} \mathrm{O}_{4}$ had a positively charged at $\mathrm{pH}<7.2$ and negatively charged at $\mathrm{pH}>7.2$, the $\mathrm{pKa}$ values of the tetracycline molecule were 3.3, 7.7 and 9.27, respectively. Tetracycline occur as cationic in strong acid solution at $\mathrm{pH}<3.3$, zwitter anions at $3.3<\mathrm{pH}<7.7$ and negative ions at $\mathrm{pH}>7.7$. As is evident, adsorption mechanisms have been given based on $\mathrm{pH}$ values were given in Table (4). Positively charge $\mathrm{Co}_{3} \mathrm{O}_{4}<$ pHpzc < egatively charge $\mathrm{Co}_{3} \mathrm{O}_{4}$ Table (1) Normally, it is always easier to adsorb a cation on a negatively charged surface, and an anion on a positively charged surface. However, other interactions may be stronger than purely electrostatic forces, making the effect of surface charge not so important. Additionally, a cation is often complexed with ligands, some of them being possibly negatively charged. Therefore, in such a case, the cation is in fact a negative complex, which may adsorb very well on a positively charged surface and that happen in this study. As showed when $\mathrm{pH}$ values were low, the cation exchange mechanism between tetracycline cation and positively charged $\mathrm{Co}_{3} \mathrm{O}_{4}$ was predominant [24-25]. Fig.(10 a and b) is shown the UV-Visible spectra of tetracycline before and after the adsorption process. 


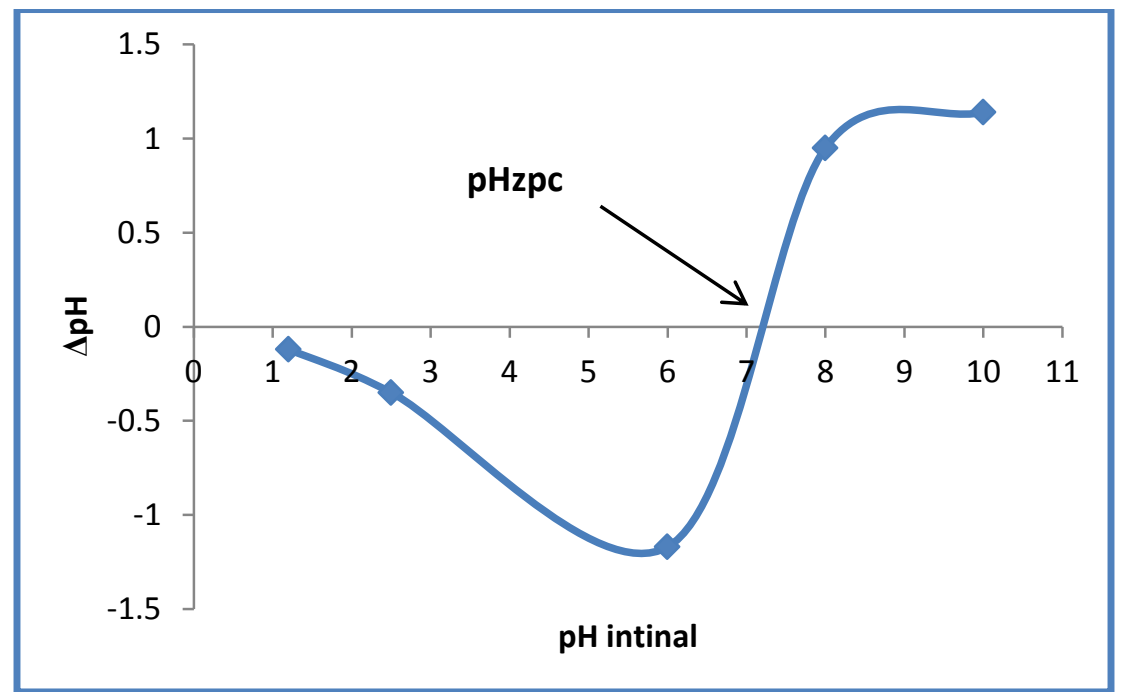

Fig.(9): The point of zero charges of $\mathrm{Co}_{3} \mathrm{O}_{4}$.

Table (1)

Adsorption mechanisms depending on $\mathrm{pH}$ values.

\begin{tabular}{||c|c|}
\hline Studied $\mathrm{pH}$ range & Adsorption Mechanisms \\
\hline \hline $2.0<\mathrm{pH}<3.0$ & Cation exchange \\
\hline \hline $3.0<\mathrm{pH}<7.0$ & Cation exchange and surface complexation \\
\hline \hline $\mathrm{pH} 8.0$ & Surface complexation \\
\hline
\end{tabular}
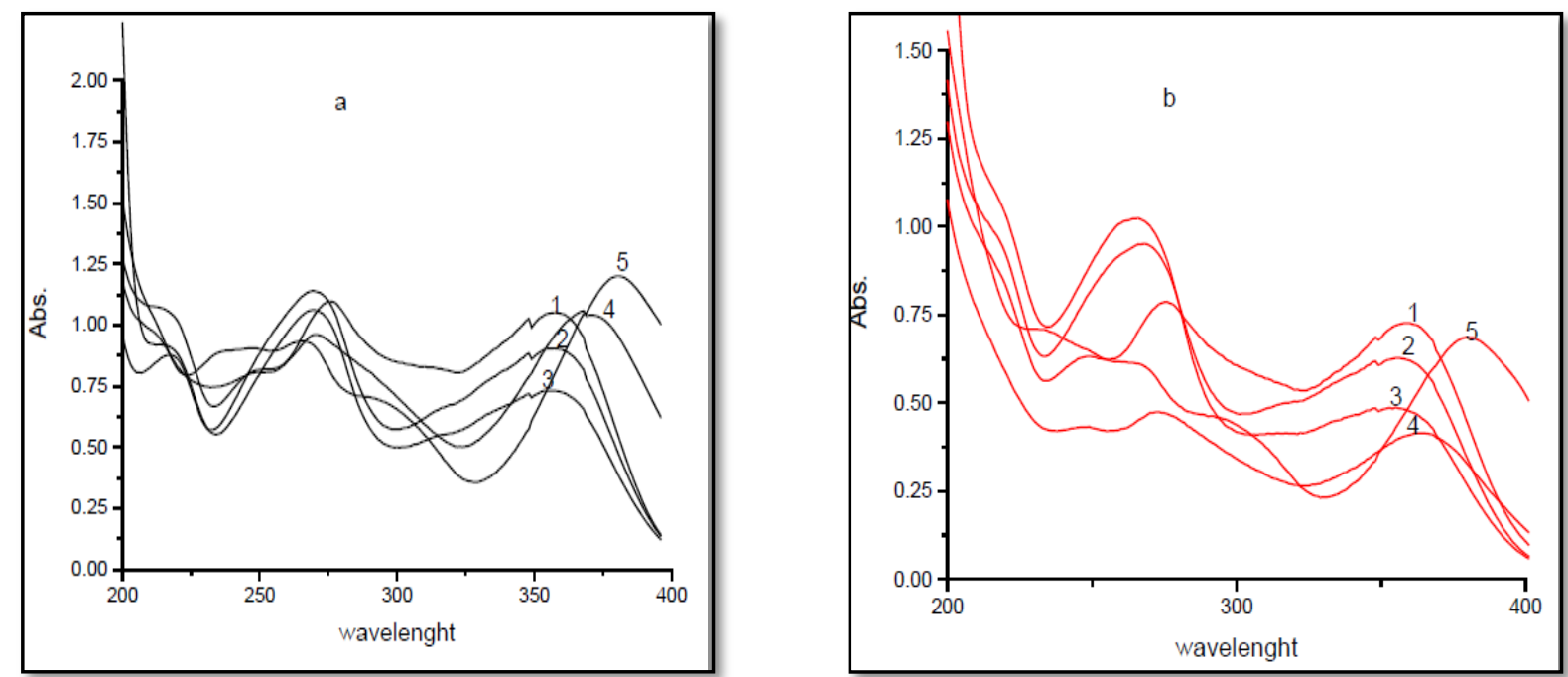

Fig.(10): $U V$ spectra of tetracycline a- before $b$ - after adsorption process $(1=p H$ 6, $2=p H 1.5$, $3=p H 3,4=p H 8$ and $5=p H 10)$.

\section{Adsorption isotherm}

The equilibrium data isotherm analysis for tetracycline adsorption onto cobalt oxide at various concentrations $(20-70 \mathrm{mg} / \mathrm{L})$ and $37{ }^{\circ} \mathrm{C}$, the adsorption data were fitted to the two widely used isotherm models, the Freundlich and Langmuir models.

$\frac{1}{\mathrm{qe}}=\frac{1}{\mathrm{qmKaCe}}+\frac{1}{\mathrm{qm}}$

$\log \left(\mathrm{q}_{\mathrm{e}}\right)=1 / \mathrm{n} \log \left(\mathrm{C}_{\mathrm{e}}\right)+\log \left(\mathrm{K}_{\mathrm{F}}\right)$.
$\mathrm{C}_{\mathrm{e}}$ is the equilibrium concentration $(\mathrm{mg} / \mathrm{L})$, where $\mathrm{q}_{\mathrm{m}}$ and $\mathrm{q}_{\mathrm{e}}(\mathrm{mg} / \mathrm{g})$ are tetracycline uptakes at saturation and equilibrium states, respectively, $\mathrm{K}_{\mathrm{a}}(\mathrm{L} / \mathrm{mg})$ is the Langmuir constant, KF mg.g ${ }^{-1}\left(\mathrm{~L}_{\mathrm{mg}} \mathrm{m}^{-1}\right)^{1 / \mathrm{n}}$ and $\mathrm{n}$ are Freundlich parameters.

The results confirm the best analysis of isotherm data by the Freundlich isotherm model. Fig.(11) and Table (2) for Freundlich isotherm show a high value for $\mathrm{R}^{2}$ of (0.99). Values of $1 / \mathrm{n}(0.88)$ where the closer value to 
zero means the more heterogeneous the adsorption surface [27-28].

Table (2)

Parameters for the Langmuir and Freundlich linear isotherm at $37^{\circ} \mathrm{C}$.

\begin{tabular}{|c|c|c|}
\hline isotherm & Constants & parameters \\
\hline \multirow{3}{*}{ Langmuir } & $\mathrm{q}_{\mathrm{a}}\left(\mathrm{mg} \cdot \mathrm{g}^{-1}\right)$ & 0.023 \\
\hline & $\mathrm{k}_{\mathrm{a}}\left(\mathrm{Lm} \cdot \mathrm{g}^{-1}\right)$ & 4.30 \\
\hline & $\mathrm{R}^{2}$ & 0.95 \\
\hline \multirow{3}{*}{ Freundlich } & $\overline{\mathrm{n}}$ & 1.12 \\
\hline & $\mathrm{K}_{\mathrm{F}}\left(\mathrm{mg} \cdot \mathrm{g}^{-1}\right)\left(\mathrm{Lmg}^{-1}\right)^{1 / n}$ & 4.48 \\
\hline & $\overline{\mathrm{R}^{2}}$ & 0.99 \\
\hline
\end{tabular}

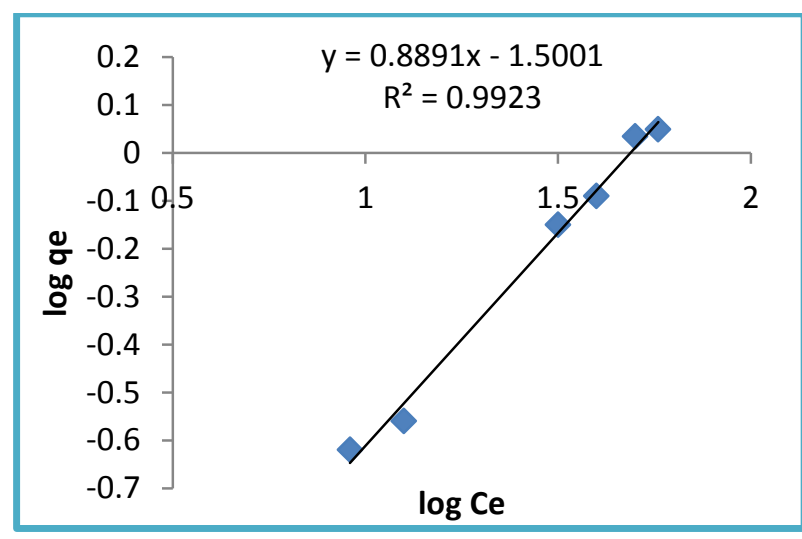

Fig.(11): Langmuir and Freundlich linear isotherm at $37^{\circ} \mathrm{C}$.

\section{Conclusions}

This paper shows that cobalt oxide can be used as an efficient adsorbent to remove tetracycline antibiotics from the aqueous solution. The effects of $\mathrm{pH}$, contact time, initial antibiotics concentration, and temperatures on the adsorption capacities have been investigated. Tow isotherm model was studies and the result show that the Freundlich models had the best fitting with data.

\section{Reference}

[1] Al-Abachi, M. Q., Al-Nedawi, Z. A. "Batch and Flow Injection Spectrophotometric determination of Tetracycline Hydrochloride and Doxycycline Hyclate in Pharmaceutical Preparations", Iraqi Journal of Science, 56 (2), 909-920, 2015.

[2] Abbas, R. F., Wheeb, A. A., Jasim, A. A. "Spectrophotometric Determination of Doxycycline Hyclate in Pure and Capsule using Diazotization Reaction", Al-Mustansiriyah Journal of Science, 27( 5), 50-54,2016.
[3] Zhu, H., Hen, T., Liu, J., Li, D. "Adsorption of tetracycline antibiotics from an aqueous solution onto graphene oxide/calcium alginate composite fibers", The Royal Society of Chemistry, 8, 26162621, 2018.

[4] Gao, Y., Li, Y., Zhang, L., Huang, H., Hua, J., Shah, S. M., Su, X. "Adsorption and removal of tetracycline antibiotics from aqueous solution by graphene oxide", Journal of Colloid and Interface Science, 3(68), 540-546, 2012.

[5] Huang, H., Zou, Y., Li, Y. "Experimental and modeling studies of sorption of tetracycline onto zeolite in the presence of Copper(II) ", Advanced Materials Research, 512-515, 2355-2360, 2012.

[6] Zhang, L., Xin, Z., Fei, X., Luo, H., Li, H., $\mathrm{Lu}, \quad$ B. "Zhongmin $\mathrm{Li}$ and Guangtao Wei "Study on adsorption of tetracycline by red mud-based ceramsite", Journal of Water Supply: Research and Technology AQUA, 68 (1), 39-50, 2018.

[7] Al-Husseini, H. K. "Adsorption of Clomid Drug On Activated Carbon And Zinc Oxide Surfaces", Journal of a collage of basic education, 88, 37-48, 2012.

[8] Khoshnamvand, N., Ahmadi, S., Mostafapour, F. K. "Kinetic and Isotherm Studies on Ciprofloxacin an Adsorption using Magnesium Oxide Nanopartices", Journal of Applied Pharmaceutical Science, 7 (11), 079-083, 2017.

[9] Kamel, B. A. "Preparation and Adsorption of [Bis(1,10-phenanthroline) nitrated(II)] nitrate Complex on Activated Carbon and Zeolite Surfaces", Journal of Al-Nahrain University, 17(3), 27-38, 2014.

[10] Ghaemi, M., Absalan G. "Fast removal and determination of doxycycline in water samples and honey by $\mathrm{Fe} 3 \mathrm{O} 4$ magnetic nanoparticles" J IRAN CHEM SOC, Vol. 12, P. 1-7, (2015).

[11] Al-Bayati, R. A. "Adsorption- Desorption of Trimethoprim Antibiotic Drug from Aqueous Solution by Two Different Natural Occurring Adsorbents", International Journal of Chemistry, 3( 3), 21-30, 2011.

[12] Al-Qaim, F. F. "Adsorption of Malachite Green (MG) on Low Cost - Adsorbent from Aqueous Solution", Journal of Babylon 
University/Pure and Applied Sciences, 1(19), 48-56, 2011.

[13] Ghati, S. K., Sulaiman, I. D, Abdulla, N. I. "Removal of Chlorpyrifos (Dursban) Pesticide from Aqueous Solutions using Barley Husks", Ibn Al-Haitham Jour. for Pure \& Appl. Sci., 29(3), 54-68, 2016.

[14] Mezcal, E. N. "Adsorption of Cefixime on to Iraqi Bentonite", Iraqi National Journal of Chemistry, 15(3), 284-295, 2015.

[15] Jafari, M., Aghamiri, S. F., Khaghanic, G. "Batch Adsorption of Cephalosporins Antibiotics from Aqueous Solution by Means of Multi-Walled Carbon Nanotubes", World Applied Sciences Journal, 14(11), 1642-1650, 2011.

[16] Azouaoua, N., Belmedani, M., Mokaddema, H., Sadaou, Z. "Adsorption of Lead from Aqueous Solution onto Untreated Orange Barks", Cheemical engineering transactions, 32, 55-60, 2013.

[17] Oskoei, V., Dehghani, M. H., Nazmara, S., Heibati, B., Asif, M., yagi, I., Agarwal, S., Gupta, V. K." Removal of humic acid from aqueous solution using $\mathrm{UV} / \mathrm{ZnO}$ nanophotocatalysis and adsorption", Journal of Molecular Liquids, 213, 374-380, 2016.

[18] Zhao, Y., Geng, J., Wang, X., Gu, X., Gao, S. "Tetracycline adsorption on kaolinite: $\mathrm{pH}$, metal cations and humic acid effects", Springer Science Business Media, 20, 1141-1147, 2011.

[19] Parolo, N. E., Savini, M. C., Vallés, J. M., Baschini, M. T., Avena, M. J. "Tetracycline adsorption on montmorillonite: $\mathrm{pH}$ and ionic strength effects", Applied Clay Science, 40, 179-186, 2008.

[20] Zhang, Z., Sun, K., Gao, B., Zhang, B., Liu, X., Zhao, Y. "Adsorption of tetracycline on soil and sediment: Effects of $\mathrm{pH}$ and the presence of $\mathrm{Cu}$ (II) ", Journal of Hazardous Materials, 190, 856-862, 2011.

[21] Ghadim, H. S, Manouchehri, F., Soleimani, G., Hosseini, H., Kimiagar, S., Nafisi, S. "Adsorption Properties of Tetracycline onto Graphene Oxide: Equilibrium, Kinetic and Thermodynamic Studies", OPLS/ONE, 8, 1-10, 2013.
[22] Avisar, D., Primor, O., Gozlan, I., Mamane, H. "Sorption of Sulfonamides and Tetracyclines to Montmorillonite Clay", Water Air Soil Pollut, 26, 1-12, 2009.

[23] Mushtaq, M., Tan, I., Ismail, L., Nadeem, M., Sagir, M., Azam, R., Hashmet, R. "Influence of PZC (Point of Zero Charge) on the Static Adsorption of Anionic Surfactants on a Malaysian Sandstone", Journal of Dispersion Science and Technology, 35, 343-349, 2014.

[24] Dolinina, E. S., Parfenyuk, E. V. "The effects of surface chemistry of mesoporous silica materials and solution $\mathrm{pH}$ on kinetics of molsidomine adsorption", Journal of Solid State Chemistry, 209, 105-112, 2014.

[25] Guler, U.A., Sarioglu, M. "Removal of tetracycline from wastewater using pumice stone: equilibrium, kinetic and thermodynamic studies", Journal of Environmental Health Science and Engineering, 12(79), 1-112014.

[26] Ching, L., Liu, Y., Syu, C., Huang, M., Tzou, Y., Teah, H. "Adsorption of tetracycline on Fe hydroxides: effects of $\mathrm{pH}$ and metal cation $\left(\mathrm{Cu}^{2+}, \mathrm{Zn}^{2+}\right.$ and $\left.\mathrm{Al}^{3+}\right)$ addition in various molar ratios", Journal of Royal Society of Chemistry. 5, 1-12, 2018.

[27] Gouamid, M., Ouahrania, M., Bensaci, M. "Adsorption Equilibrium, kinetics and thermodynamics of methylene blue from aqueous solutions using Date Palm Leaves", Journal of Energy Procedia, 36, 898 - 907, 2013.

[28] Mannaa, S., Roy, D., Sahac, P., Gopakumar, D.; Thomas, S. "Rapid methylene blue adsorption using modified lignocellulosic materials", Journal of Process Safety and Environmental Protection, 107, 346-356, 2017. 